How to cite this article:

Wahyuni, N., \& Ab-Latif, Z. (2020). Mocaf Flour As An Alternative Ingredient: A Study On Batik-Patterned Cookies. Journal Of Technology And Operations Management, 15(1), 40-49. https://doi.org/10.32890/jtom2020.15.1.3

\title{
MOCAF FLOUR AS AN ALTERNATIVE INGREDIENT: A STUDY ON BATIK-PATTERNED COOKIES
}

\author{
${ }^{1}$ Nur Wahyuni $\&^{2} \mathrm{Ab}$-Latif, $\mathrm{Z}$ \\ ${ }^{1}$ Akademi Kesejahteraan Sosial Yogyakarta, Daerah Istimewa Yogyakarta, Indonesia. \\ ${ }^{2}$ Universiti Pendidikan Sultan Idris, Tanjong Malim, Perak, Malaysia. \\ Corresponding author: zahidah@ftv.upsi.edu.my
}

\begin{abstract}
The mocaf flour also known as modified cassava flour is flour that is modified by using microbial fermentation techniques. It has similar physical and chemical characteristics that could substitute wheat flour. This study aims to obtain the composition or formula in making batik - patterned cookies as well as attaining public acceptance of the product. A series of four combinations of mocaf and wheat flour were formulated and an acceptance test was carried out on 30 panelists in Yogyakarta within August and October 2019. The findings disclosed that the cookie sample $\mathrm{X}_{3}$ with the combination of 150 gram mocaf flour and 50 gram wheat flour had the highest value $(\mathrm{M}=$ color: 3.37; aroma: 3.13; texture: 3.20; and taste: 3.33). This study is the first to assess the acceptance rate of batik - patterned cookies using mocaf flour. The significant results deepen our understandings of the demand of the consumers in order to increase selling value thus indirectly promoting the batik motifs to the consumers.
\end{abstract}

Keywords: Mocaf flour, modified cassava flour, batik, batik - patterned cookies, formulation. 


\section{INTRODUCTION}

Batik has been a major attraction in Indonesia, especially after enlisted as one of the UNESCO Intangible Cultural Heritage in 2009 (Abas \& Yuniasanti, 2019). Batik is a craft that is high in artistic value with sacred motifs as well as having intrinsic semiotic and symbolic meaning that people use it in a particular events (Yuliati \& Yudisiani, 2018; Yunus \& Tulasi, 2012). UNESCO has nominated batik for its values of special craftsmanship components and historical and sociocultural motifs (Maulia, 2009). Furthermore, the World Crafts Council designated Yogyakarta as the World Batik City in 2014 in which proves that Indonesia has become a well-known country in batik industry. Previous studies on batik suggested to promote batik as a valuable souvenirs for the visitors which indicates that batik has a significant impact on tourism (Hengky, 2015). Therefore, it is worthwhile to study on batik that could be a potential vehicle to attract visitors through events, festivals or tourism activities. Tourism attraction also can be portrayed through food. In fact, food is an integral part of the experience and provides major contribution to an individual's vacation (Cohen, 2003; Henderson, 2009; Robinson \& Getz, 2014). It shows when travelers spend more than $\$ 209$ billion annually on food service in the United States with average of one-third fine-dining sales and almost a fourth of casual-dining sales (National Restaurant Association, 2015). That is, there is a symbiotic relationship between food and the tourism industry, which could be a promotional tool for a destination.

One of the food that draw people attention in Yogyakarta is their well known cookies made of wheat flour, sugar, eggs, and vanilla (Braker, 2003). In general, cookies have a sweet taste and crunchy texture, with the baking process carried out twice. Many cookies are sold in the market, but almost entirely made from wheat flour as the main ingredient. As a consequence, the consumption of wheat flour in Indonesia continues to increase when $95 \%$ of food made of wheat flour (Soesilowati et al., 2020). In fact, $100 \%$ of wheat is imported by Indonesia. The dependency on imported wheat flour by Indonesian exhibits a total of 934.7 tons with value of US \$167.2 million of wheat flour been imported in April 2017 (Soesilowati et al., 2020). Therefore, in means to reduce expenses and dependency on wheat flour, this current study aim to introduce batikpatterned cookies made of ingredient other than wheat flour. Therefore, the utilization of mocaf flour is recommended as a substitution of common flour used.

\section{MATERIALS AND METHODS}

The mocaf flour derived from modified cassava flour is flour made of cassava, which is made through a fermentation process by using bacteria from lactic acid (Subagio, 2009). The process is different from producing cassava flour that does not go through a fermentation process but uses bacterial microbes. The mocaf flour has good prospects in terms of three aspects: 1) the availability of cassava as an abundant source of raw materials, so that the availability of material is guaranteed because it is locally produced, 2) the price of mocaf flour on the market is relatively cheaper than the price of wheat flour or rice flour, and 3) mocaf flour has prospects in the local market because it can be absorbed by most food industries that still use flour as their main raw material (Subagio, 2011).

Several characteristics of mocaf flour are almost as the same as wheat flour that makes it a good substitute for flour. According to Subagio (2009), mocaf has been tested to be 
used for a variety of pastries, such as cookies and cake. For instance, $50-100 \%$ use of mocaf flour is added in cookies, cheese sticks, steamed bread, and cakes such as dodol, candil porridge, and klepon, while only $30-40 \%$ use of mocaf flour is added in producing bread, pastry, and noodles. Mocaf flour is fermented cassava flour which is able to compete economically with wheat flour. With the source of cassava which is cheap and easily obtained and can use simple technology, the price of mocaf flour can be $40-60 \%$ cheaper than the price of wheat flour (Soesilowati et al., 2020). In addition, mocaf flour usage is considered economical due to the durability is much longer than cookies made of wheat flour. Moreover, higher sugar content in cassava will results in the more reasonable use of sugar or other sweetening ingredients while producing cookies (Soesilowati et al., 2020). Therefore, this experimental study through a complete randomized research design that was conducted between August and October 2019, tested the batik-patterned cookies with four combinations of wheat flour and mocaf flour, namely sample $\mathrm{X}_{1}(0 \mathrm{gm}: 200 \mathrm{gm}) ; \mathrm{X}_{2}(100 \mathrm{gm}: 100 \mathrm{gm}) ; \mathrm{X}_{3}(150 \mathrm{gm}$ : 50gm); and $\mathrm{X}_{4}$ (200gm: 0gm).

\section{Materials}

The following are the materials and tools used in this study:

\section{Table 1.}

Batik-patterned cookies ingredients

\begin{tabular}{cccc}
\hline No & Material Name & Amount & Specification (Brand) \\
\hline 1. & Mocaf flour & 1000 gram & KWT Kusuma \\
2. & Wheat & 200 gram & Bunga sari \\
3. & Sugar & 750 gram & Gulaku \\
4. & Egg & 1 no & - \\
5. & Coconut milk & 500 gram & Kara \\
6. & Cocoa powder & 75 gram & van houten \\
7. & Salt & $3 \mathrm{tsp}$ & Revina \\
\hline
\end{tabular}

Table 2.

Batik-patterned cookies formula

\begin{tabular}{|c|c|c|c|c|c|}
\hline No & Material Name & $\mathrm{X}_{1}$ & $X_{2}$ & $\mathrm{X}_{3}$ & $X_{4}$ \\
\hline 1. & Mocaf flour & 0 gram & 100 gram & 150 gram & 200 gram \\
\hline 2. & Wheat & 200 gram & 100 gram & 50 gram & 0 gram \\
\hline 3. & Egg & \multicolumn{4}{|c|}{5 nos } \\
\hline 4. & Sugar & \multicolumn{4}{|c|}{250 gram } \\
\hline 5. & Coconut milk & \multicolumn{4}{|c|}{150 gram } \\
\hline 6. & Cocoa powder & \multicolumn{4}{|c|}{25 gram } \\
\hline 7. & Salt & \multicolumn{4}{|c|}{$1 \mathrm{tsp}$} \\
\hline
\end{tabular}

\section{Tools}

The equipment used in carrying out this research was selected whose conditions are still good and hygienic, namely as follows: 


\section{Table 3.}

The list of equipment for making batik-patterned cookies

\begin{tabular}{ccc}
\hline No & Material Name & Amount \\
\hline 1. & Measuring scale & 1 \\
2. & Batter machine & 3 \\
3. & Mixer & 1 \\
4. & Measuring jar & 1 \\
5. & Brass & 3 \\
6. & Spatula & 3 \\
7. & Square steamer & 1 \\
8. & Oven & 1 \\
\hline
\end{tabular}

\section{Testing Method}

The tests have been carried out through organoleptic and hedonic tests (sensory) on the four samples as described above. The organoleptic properties included color, aroma, texture, and taste of batik-patterned cookies been verified from 30 panelists that were measured using a 4-point Likert scale ranging from 1 (very dislike), 2 (dislike), 3 (like), and 4 (really like). The data were analyzed using descriptive analysis and one-way ANOVA in order to examine the differences in each four samples of cookies with a posthoc test through Duncan Multiple Range Test (DMRT). The results were analyzed using statistical package for the social sciences (SPSS) version 21.

\section{The process}

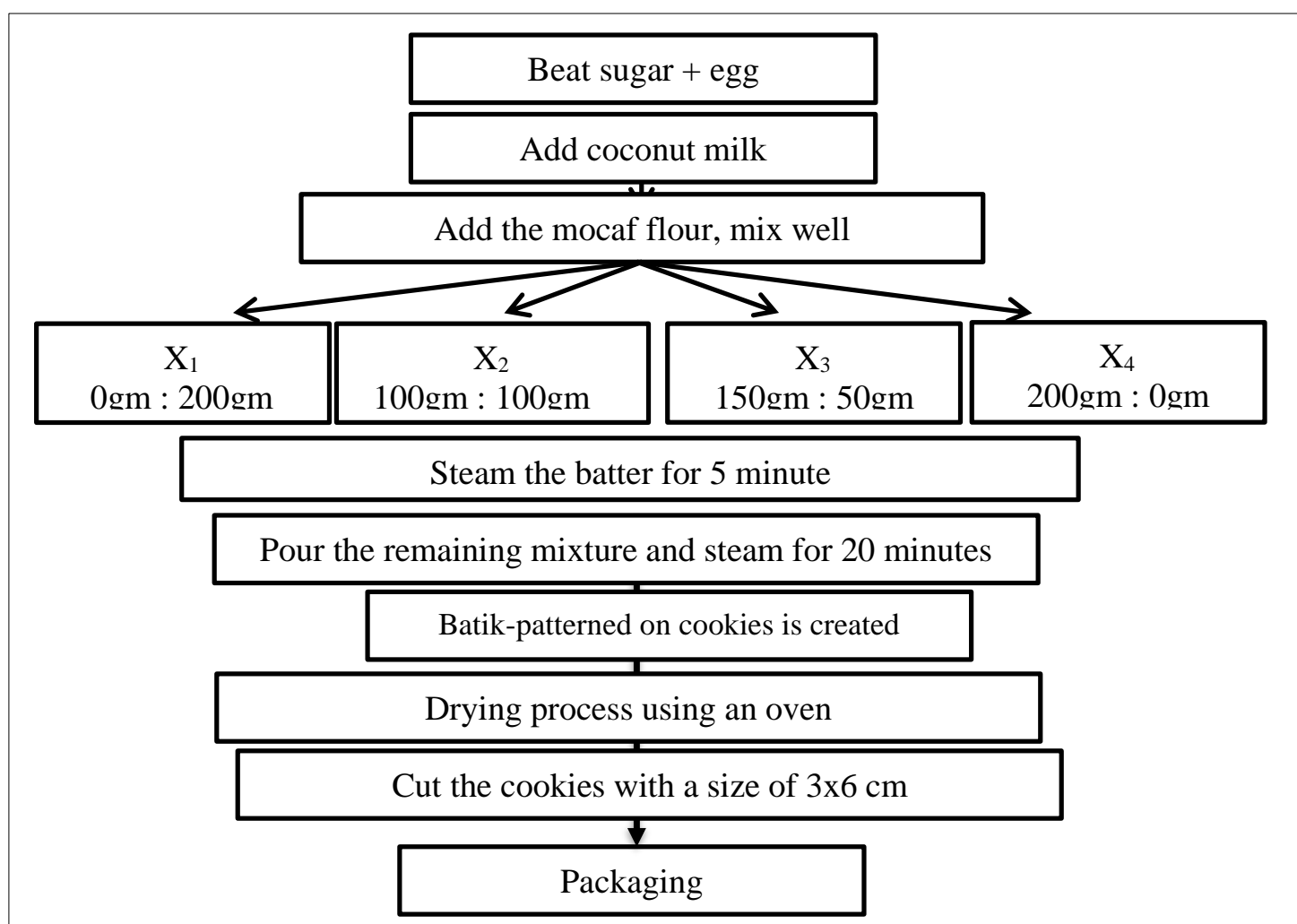

Figure 1. Flow chart of batik-patterned cookies making process 
The steps and procedures of making the batik-patterned cookies with 3 different kinds of treatment are as shown in figure 1 .

\section{RESULTS AND DISCUSSION}

Results exhibit the characteristics of four samples batik-patterned cookies including color, aroma, texture, and taste are described below:

Table 4.

Characteristics of batik-patterned cookies batik motifs with four formulas

\begin{tabular}{|c|c|c|c|c|}
\hline \multirow{2}{*}{ Characteristic } & \multicolumn{4}{|c|}{ Sample Test } \\
\hline & $\mathrm{X}_{1}$ & $\mathrm{X}_{2}$ & $\mathrm{X}_{3}$ & $\mathrm{X}_{4}$ \\
\hline Color & $\begin{array}{l}\text { Brownish } \\
\text { white }\end{array}$ & Opaque white & Pale white & Milk White \\
\hline Aroma & $\begin{array}{l}\text { The aroma } \\
\text { of flour } \\
\text { cake }\end{array}$ & $\begin{array}{l}\text { The aroma of } \\
\text { flour is mixed } \\
\text { with a little } \\
\text { cassava }\end{array}$ & $\begin{array}{c}\text { The aroma of cassava } \\
\text { is rather strong }\end{array}$ & $\begin{array}{l}\text { Strong } \\
\text { cassava } \\
\text { aroma }\end{array}$ \\
\hline Texture & Solid & $\begin{array}{c}\text { Compact is a bit } \\
\text { heavy }\end{array}$ & $\begin{array}{l}\text { Compact, lightweight, } \\
\text { comfortable }\end{array}$ & $\begin{array}{l}\text { Lightweight } \\
\text { and } \\
\text { comfortable }\end{array}$ \\
\hline Taste & $\begin{array}{l}\text { The } \\
\text { special } \\
\text { taste of } \\
\text { flour cake }\end{array}$ & $\begin{array}{c}\text { Flavor the cake } \\
\text { with a little } \\
\text { cassava }\end{array}$ & $\begin{array}{c}\text { A balanced } \\
\text { combination of flour } \\
\text { and cassava flavors }\end{array}$ & $\begin{array}{c}\text { Cassava } \\
\text { flavors }\end{array}$ \\
\hline
\end{tabular}

Notes:

$X_{1}$ : The combination of batik-patterned cookies with $0 \mathrm{gm}$ mocaf flour and $200 \mathrm{gm}$ flour

$X_{2}$ : The combination of batik-patterned cookies with 100gm mocaf flour and $100 \mathrm{gm}$ flour

$X_{3}$ : The combination of batik-patterned cookies with 150gm mocafflour and $50 \mathrm{gm}$ flour

$X_{4}$ : The combination of batik-patterned cookies with $200 \mathrm{gm}$ mocaf flour and $0 \mathrm{gm}$ flour

Based on observations that have been made on the research sample, it can be seen that the formulation of mocaf flour and wheat flour can influence the color of the batikpatterned cookies. The color changed from brownish white in sample $\mathrm{X}_{2}$, then changes to white according to the increasing amount of mocaf flour content, in order of the samples $\mathrm{X}_{2}$ and $\mathrm{X}_{3}$. Even the $\mathrm{X}_{4}$ sample produced a milky white color. This happens because the addition of mocaf flour can make the cake whiter. By increasing the amount of mocaf flour added to the sample, it can increase the level of white in the resulting sample, even in sample $\mathrm{X}_{4}$ producing batik-patterned cookies which is milky white because there is no flour which makes the cake batik-patterned cookies white brown. The aroma of batik-patterned cookies in sample $\mathrm{X}_{1}$ tends to still be flavored with flour cakes, whereas in sample $\mathrm{X} 4$ it has a strong cassava flavor. This is presumably because mocaf flour has a strong cassava aroma, so the aroma of cassava is getting stronger in accordance with the addition of mocaf flour.

The texture of batik-patterned cookies with the addition of mocaf flour variants produces the characteristics of batik-patterned cookies which is dense in sample $\mathrm{X}_{1}$, dense slightly weakened in sample $\mathrm{X}_{2}$, solid, light, weakened in sample $\mathrm{X}_{3}$, and mild 
and weakened in sample $\mathrm{X}_{4}$. The addition of mocaf flour can reduce the density level of batik-patterned cookies so that it has a weak texture. The texture of cake in sample $\mathrm{X}_{4}$ can adjust to the character of sponge cake which is not too dense but light.

The batik-patterned cookies of sample $\mathrm{X}_{1}$ still shows the distinctive taste of wheat flour, while the batik motif of cookies with the addition of different mocaf flour shows a change in flavor which slowly reduces the taste of flour cake. Even up to sample $\mathrm{X}_{4}$, it showed a sample of batik-patterned cookies with cassava flavor. A balanced flavor between flour and mocaf flour was found in sample $\mathrm{X}_{3}$.

\section{Color}

Table 6.

Organoleptic test results of color of batik-patterned cookies

\begin{tabular}{ccccccccc}
\hline & \multicolumn{7}{c}{ Sample Test } \\
\cline { 2 - 10 } Criteria & \multicolumn{2}{c}{$\mathrm{X}_{1}$} & \multicolumn{2}{c}{$\mathrm{X}_{2}$} & \multicolumn{2}{c}{$\mathrm{X}_{3}$} & \multicolumn{2}{c}{$\mathrm{X}_{4}$} \\
\cline { 2 - 10 } & $\mathrm{F}$ & $\%$ & $\mathrm{~F}$ & $\%$ & $\mathrm{~F}$ & $\%$ & $\mathrm{~F}$ & $\%$ \\
\hline Really Like & 0 & $0,0 \%$ & 0 & $0,0 \%$ & 13 & $43,3 \%$ & 5 & $16,7 \%$ \\
Like & 8 & $26,7 \%$ & 17 & $56,7 \%$ & 15 & $50,0 \%$ & 16 & $53,3 \%$ \\
Dislike & 20 & $66,7 \%$ & 12 & $40,0 \%$ & 2 & $6,7 \%$ & 9 & $30,0 \%$ \\
Very Dislike & 2 & $6,7 \%$ & 1 & $3,3 \%$ & 0 & $0,0 \%$ & 0 & $0,0 \%$ \\
\hline Total & 30 & 100,00 & 30 & 100,00 & 30 & 100,00 & 30 & 100,00 \\
\hline Average & \multicolumn{2}{c}{2,20} & \multicolumn{2}{c}{2,53} & & 3,37 & & 2,87 \\
\hline
\end{tabular}

The hedonic test for the dry color of batik-patterned cookies shows that sample $\mathrm{X}_{3}$ (150gm wheat flour: $50 \mathrm{gm}$ mocaf flour) had the highest average score of 3.37. These results indicate that the panelists preferred the dry color of the batik motif in sample $\mathrm{X}_{3}$.

Table 7.

Test results for one-way ANOVA and Duncan test for dry color of batik-patterned cookies

\begin{tabular}{|c|c|c|c|c|c|c|c|c|}
\hline \multirow{2}{*}{ Sample } & \multirow{2}{*}{$\mathrm{N}$} & \multicolumn{4}{|c|}{ Subset for Alpha $=0,05$} & \multirow{2}{*}{ Fhitung } & \multirow{2}{*}{$\mathrm{F}_{\text {tabel }}$} & \multirow{2}{*}{ Sig. } \\
\hline & & 1 & 2 & 3 & 4 & & & \\
\hline $\mathrm{X}_{1}(0 \mathrm{gm}: 200 \mathrm{gm})$ & 30 & 2,20 & \multirow{4}{*}{2,53} & & & \multirow{4}{*}{20,19} & \multirow{4}{*}{2,68} & \multirow{4}{*}{0,000} \\
\hline $\mathrm{X}_{2}(100 \mathrm{gm}: 100 \mathrm{gm})$ & 30 & & & \multirow{3}{*}{3,37} & & & & \\
\hline $\mathrm{X}_{4}(150 \mathrm{gm}: 50 \mathrm{gm})$ & 30 & & & & & & & \\
\hline $\mathrm{X}_{3}(200 \mathrm{gm}: 0 \mathrm{gm})$ & 30 & & & & 2,87 & & & \\
\hline
\end{tabular}

Based on the one-way ANOVA test on samples of dry color of batik-patterned cookies, the value of $F_{\text {count }}(20.19)>F_{\text {table }}(2.68)$ and $\operatorname{Sig}(0.000)<0.05$, which indicates that there are differences in the color of the batik-patterned cookies color on all four test samples. The post-hoc test continued with the DMRT test which showed that all four samples had significant differences. The color factor provides initial visuals on determining whether a food is nutritious, tasty, and has a very good texture. Conversely, if the food 
has a color that is less attractive or gives the impression has deviated from the color that should be then it will not be eaten. This shows that the color has an important role in the reception of food. Apart from being a factor that determines quality, color can also be used as an indicator of the quality of mixing or processing through uniform and uniform food colors (Winarno, 2002).

\section{Aroma}

Table 8.

Organoleptic analysis of aroma of batik-patterned cookies

\begin{tabular}{ccccccccc}
\hline \multirow{2}{*}{ Criteria } & \multicolumn{7}{c}{ Sample Test } \\
\cline { 2 - 10 } & $\mathrm{F}$ & $\mathrm{X}_{1}$ & $\mathrm{X}$ & $\%$ & $\mathrm{~F}$ & $\%$ & $\mathrm{~F}$ & $\%$ \\
\cline { 2 - 10 } & 0 & $0,00 \%$ & 1 & $3,33 \%$ & 8 & $26,67 \%$ & 5 & $16,67 \%$ \\
\hline Really Like & 13 & $43,33 \%$ & 17 & $56,67 \%$ & 18 & $60,00 \%$ & 15 & $50,00 \%$ \\
Like & 15 & $50,00 \%$ & 12 & $40,00 \%$ & 4 & $13,33 \%$ & 10 & $33,33 \%$ \\
Dislike & 2 & $6,67 \%$ & 0 & $0,00 \%$ & 0 & $0,00 \%$ & 0 & $0,00 \%$ \\
Very Dislike & 30 & 100,00 & 30 & 100,00 & 30 & 100,00 & 30 & 100,00 \\
\hline Total & \multicolumn{2}{c}{2,37} & 2,63 & & 3,13 & 2,83 \\
\hline Average & & 7
\end{tabular}

The hedonic test for the aroma of batik-patterned cookies showed that sample $\mathrm{X}_{3}$ (150gm wheat flour: $50 \mathrm{gm}$ mocaf flour) produced the highest average score of 3.13. These results indicated that the panelists preferred the aroma of $150 \mathrm{gm}$ wheat flour: $50 \mathrm{gm}$ mocaf flour in sample $\mathrm{X}_{3}$.

Table 9.

Results of one-way ANOVA test and Duncan test of aroma of batik-patterned cookies

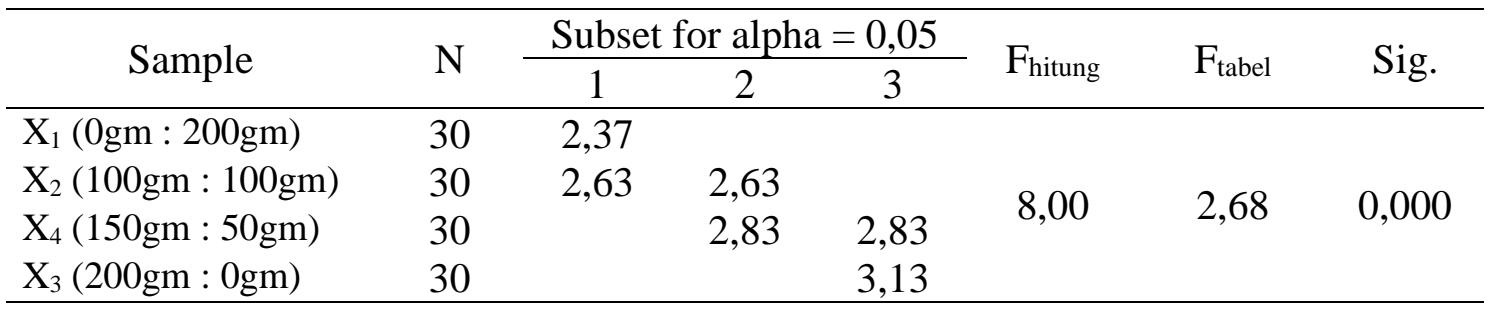

Based on the one-way ANOVA test on the sample of batik-patterned cookies aroma, the value of $F_{\text {count }}(8.00)>F_{\text {table }}(2.68)$ and Sig value $(0.000)<0.05$, which indicates that there are differences in the aroma of batik-patterned cookies of all four test samples. The post-hoc test continued with the DMRT test which showed that samples that were not significantly different were in sample $X_{1}$ and sample $X_{2}$; sample $X_{2}$ with sample $\mathrm{X}_{4}$; and sample $\mathrm{X}_{4}$ with sample $\mathrm{X}_{3}$.

Panelists favored the batik-patterned cookies in sample $X_{3}$ because they had a strong aroma of flour but had a less strong aroma of cassava. This aroma is a new thing for panelists where most cakes rarely have the aroma of cassava, so it can be an attraction for consumers who want to try something new in food. 


\section{Texture}

Table 10.

Results of organoleptic analysis of texture of batik-patterned cookies

\begin{tabular}{ccccccccc}
\hline & \multicolumn{7}{c}{ Sampel Test } \\
\cline { 2 - 10 } Criteria & \multicolumn{2}{c}{$\mathrm{X}_{1}$} & \multicolumn{1}{c}{$\mathrm{X}_{2}$} & \multicolumn{2}{c}{$\mathrm{X}_{3}$} & \multicolumn{2}{c}{$\mathrm{X}_{4}$} \\
\cline { 2 - 10 } & $\mathrm{F}$ & $\%$ & $\mathrm{~F}$ & $\%$ & $\mathrm{~F}$ & $\%$ & $\mathrm{~F}$ & $\%$ \\
\hline Very Like & 1 & $3,33 \%$ & 2 & $6,67 \%$ & 10 & $33,33 \%$ & 4 & $13,33 \%$ \\
Like & 11 & $36,67 \%$ & 15 & $50,00 \%$ & 16 & $53,33 \%$ & 18 & $60,00 \%$ \\
Dislike & 16 & $53,33 \%$ & 12 & $40,00 \%$ & 4 & $13,33 \%$ & 7 & $23,33 \%$ \\
Very Dislike & 2 & $6,67 \%$ & 1 & $3,33 \%$ & 0 & $0,00 \%$ & 1 & $3,33 \%$ \\
\hline Total & 30 & 100,00 & 30 & 100,00 & 30 & 100,00 & 30 & 100,00 \\
\hline Average & & 2,37 & & 2,60 & & 3,20 & & 2,83 \\
\hline
\end{tabular}

The hedonic test for the texture of batik-patterned cookies showed that sample $\mathrm{X}_{3}$ (150gm wheat flour: $50 \mathrm{gm}$ mocaf flour) had the highest average score of 3.00. These results indicate that the panelists preferred the texture of the batik-patterned cookies in sample $\mathrm{X}_{3}$.

Table 11.

Results of one-way ANOVA test and Duncan test of texture of batik-patterned cookies

\begin{tabular}{|c|c|c|c|c|c|c|c|}
\hline \multirow{2}{*}{ Sample } & \multirow{2}{*}{$\mathrm{N}$} & \multicolumn{3}{|c|}{ Subset for alpha $=0,05$} & \multirow{2}{*}{$\mathrm{F}_{\text {hitung }}$} & \multirow{2}{*}{$\mathrm{F}_{\text {tabel }}$} & \multirow{2}{*}{ Sig. } \\
\hline & & 1 & 2 & 3 & & & \\
\hline $\mathrm{X}_{1}(0 \mathrm{gm}: 200 \mathrm{gm})$ & 30 & 2,37 & & & & & \\
\hline $\mathrm{X}_{2}(100 \mathrm{gm}: 100 \mathrm{gm})$ & 30 & 2,60 & 2,63 & & 800 & 268 & 0000 \\
\hline $\mathrm{X}_{4}(150 \mathrm{gm}: 50 \mathrm{gm})$ & 30 & & 2,83 & & 8,00 & 2,08 & 0,000 \\
\hline $\mathrm{X}_{3}(200 \mathrm{gm}: 0 \mathrm{gm})$ & 30 & & & 3,20 & & & \\
\hline
\end{tabular}

Based on the one-way ANOVA test on the sample texture of batik-patterned cookies, obtained $F_{\text {count }}$ value $(4,536)>F_{\text {table }}(2.68)$ and Sig value $(0,000)<0.05$, which indicates that there are differences in the texture of dry batik cake texture on all four test samples. The post-hoc test continued with the DMRT test which showed that samples that were not significantly different were in sample $\mathrm{X}_{1}$ and sample $\mathrm{X}_{2}$; and sample $\mathrm{X}_{2}$ with sample $\mathrm{X}_{4}$.

The batik-patterned cookies in sample $\mathrm{X}_{3}$ has the characteristics of texture, which is not too dense but light and weak. This can be an attraction of cake products with a light texture character, so panelists can enjoy sponge cakes that have a character that is not too dense but light and weak. 
Taste

Table 12.

Results of organoleptic analysis of taste of batik-patterned cookies

\begin{tabular}{ccccccccc}
\hline & \multicolumn{7}{c}{ Test Sample } \\
\cline { 2 - 9 } Criteria & \multicolumn{2}{c}{$\mathrm{X}_{1}$} & \multicolumn{2}{c}{$\mathrm{X}_{2}$} & \multicolumn{2}{c}{$\mathrm{X}_{3}$} & $\mathrm{X}_{4}$ \\
\cline { 2 - 10 } & $\mathrm{F}$ & $\%$ & $\mathrm{~F}$ & $\%$ & $\mathrm{~F}$ & $\%$ & $\mathrm{~F}$ & $\%$ \\
\hline Very Like & 0 & $0,00 \%$ & 4 & $13,33 \%$ & 12 & $40,00 \%$ & 5 & $16,67 \%$ \\
Like & 12 & $40,00 \%$ & 15 & $50,00 \%$ & 16 & $53,33 \%$ & 14 & $46,67 \%$ \\
Dislike & 17 & $56,67 \%$ & 11 & $36,67 \%$ & 2 & $6,67 \%$ & 9 & $30,00 \%$ \\
Very Dislike & 1 & $3,33 \%$ & 0 & $0,00 \%$ & 0 & $0,00 \%$ & 2 & $6,67 \%$ \\
\hline Total & 30 & 100,00 & 30 & 100,00 & 30 & 100,00 & 30 & 100,00 \\
\hline Average & \multicolumn{2}{c}{2,37} & & 2,77 & & 3,33 & 2,73 \\
\hline
\end{tabular}

The test for the batik-patterned cookies showed that sample $X_{3}(150 \mathrm{gm}$ wheat flour: $50 \mathrm{gm}$ mocaf flour) had the highest average score of 3.33. These results indicated that the panelists preferred the taste of batik-patterned cookies in sample $X_{3}$.

Table 13.

Results of one-way ANOVA test and Duncan test of taste of batik-patterned cookies

\begin{tabular}{|c|c|c|c|c|c|c|c|}
\hline \multirow{2}{*}{ Sample } & \multirow{2}{*}{$\mathrm{N}$} & \multicolumn{3}{|c|}{ Subset for Alpha $=0,05$} & \multirow{2}{*}{$\mathrm{F}_{\text {count }}$} & \multirow{2}{*}{$\mathrm{F}_{\text {table }}$} & \multirow{2}{*}{ Sig. } \\
\hline & & 1 & 2 & 3 & & & \\
\hline $\mathrm{X}_{1}(5 \mathrm{gm}+45 \mathrm{gm})$ & 30 & 2,37 & & & \multirow{4}{*}{10,48} & \multirow{4}{*}{2,68} & \multirow{4}{*}{0,000} \\
\hline $\mathrm{X}_{4}(25 \mathrm{gm}+25 \mathrm{gm})$ & 30 & & 2,73 & & & & \\
\hline$X_{2}(10 g m+40 g m)$ & 30 & & 2,77 & & & & \\
\hline $\mathrm{X}_{3}(15 \mathrm{gm}+35 \mathrm{gm})$ & 30 & & & 3,33 & & & \\
\hline
\end{tabular}

Based on the one-way ANOVA test on the taste of batik-patterned cookies samples, obtained $F_{\text {count }}(10.48)>F_{\text {table }}(2.68)$ and $\operatorname{Sig}(0.000)<0.05$, which indicated that there are differences in the taste of batik motif cookies on all four test samples. The post-hoc test continued with the DMRT test which showed that samples that were not significantly different were in sample $\mathrm{X}_{4}$ and sample $\mathrm{X}_{2}$. The batik-patterned cookies in sample $\mathrm{X}_{3}$ have a balanced blend of flour and cassava cakes. This is an interesting thing for panelists because most cake products are having a distinctive flour flavor, so that with a balanced combination between the taste of flour cakes and the taste of cassava cakes can make this sample the most preferred by panelists.

\section{CONCLUSIONS AND SUGGESTIONS}

Based on the results of the study, it can be concluded in the organoleptic test that showed samples of batik-patterned cookies $X_{3}$ (150gm mocaf flour: $50 \mathrm{gm}$ wheat flour) were more preferred by panelists because they had a color that was not too white; the aroma of cassava is not too sharp; dense, light and flawless texture; and balanced flavor of flour cakes and cassava. Based on the results of the study, the suggestions in this study are: 1) To government institutions so that they can consider the use of mocaf flour as an alternative food ingredient besides wheat flour; 2) To researchers in order to be 
able to socialize the use of mocaf flour as an alternative food ingredient in making batik motif cookies; 3) It is recommended for business people (UKM) to develop the mocaf flour industry through the substitution of flour with mocaf flour in the manufacture of processed food products, especially in the development of food products because it provides flavors that are not inferior to the original product.

\section{ACKNOWLEDGMENT}

This research received no specific grant from any funding agency in the public, commercial, or not-for-profit sectors. .

\section{REFERENCES}

Abas, N. A. H., \& Yuniasanti, R. (2019). Translation and adaptation culture: Experience workplace incivility scale in Indonesia. Asian Journal of Assessment in Teaching and Learning, 9(1), 1-15.

Braker, F. (2003). The simple art of perfect baking. New York: Chronicle Books.

Cohen, D. (2003). Australia has become the academic destination for much of Asia. Can it handle the influx. The Chronicle of Higher Education, 49(21), A40.

Henderson, J. (2009). Food tourism reviewed. British Food Journal, 111(4), 317-326.

Hengky, S. H. (2015). Beneficial images: Batik handicraft tourism in Yogyakarta, Indonesia. Bus Econ Res, 11-23.

Maulia, E. (2009). Batik selected for UNESCO cultural heritage list. Jakarta Post, 8 September, http://www.thejakartapost.com/news/2009/09/08/batik-selectedunescocultural-heritage-list.html. Accessed August 24, 2019.

National Restaurant Association (NRA) (2015). Facts at a glance. Available at: www.restaurant.org/research/facts. Accessed September 20, 2019.

Robinson, R. N., \& Getz, D. (2014). Profiling potential food tourists: An Australian study. British Food Journal, 116(4), 660-706. DOI 10.1108/BFJ-02-2012-0030.

Soesilowati, E., Martuti, N. K. T., \& Paramita, O. (2020). Business feasibility of mocaf flour products, cassava starch, purple sweet potato and yellow yams. Journal of Social Sciences Research, 6(2), 167-172. doi.org/10.32861/jssr.62.167.172.

Subagio, A. (2009). Modified cassava flour sebuah masa depan ketahanan pangan nasional berbasis potensi lokal. Jember: FTP Universitas Jember.

Subagio, A. (2011). Pengembangan Agribisnis Tepung Mocaf di Tanjungsari, Gunungkidul. Prosiding Seminar Hasil Penelitian Tanaman Aneka Kacang dan Umbi.

Yuliati, Y., \& Yudisiani, Y. (2018). Effect of batik nusantara bengkulu karnaval on purchase decision of batik besurek. In Proceeding International Conference on Media and Communications in Southeast Asia, Surabaya, Indonesia.

Yunus, U., \& Tulasi, D. (2012). Batik Semiotics as a media of communication in Java. Cultura, 9(2), 143-150.

Winarno, F. G. (2002). Kimia pangan dan gizi. Jakarta: Gramedia. 